\title{
A Correlational Study Investigating Students' Activities in STAD Model and Their Interest in Learning English
}

\author{
Albiansyah $^{1^{*}}$, Endah Hardiyanti ${ }^{2}$ \\ ${ }^{1}$ Departement of English Language Education, Universitas Islam Negeri Syarif Hidayatullah, \\ Jakarta, Indonesia. \\ ${ }^{2}$ Departement of English Language Education, Universitas Islam Indragiri, Tembilahan, \\ Indonesia. \\ ${ }^{*}$ Corresponding author: \\ Email: albiaansyah@gmail.com
}

\begin{abstract}
.
The study attempts to know the significant correlation between students' Activities in STAD Model and their interest in learning English. This study was a correlational study designed to determine whether and how a set of variables had related to each other. The participants were 50 students in the first year of high school. The instruments used in this study were observation sheet and questionnaire. Observation sheet is used to find out the category of students' activities in STAD model and give a questionnaire consisting of seven items to the students. SPSS was used to analyze the data. The score of product-moment by using SPSS, $R_{x y}$ is $(0,410)$ : it showed there was a significant correlation between students' activities in STAD model and their interest in learning English. Referring to the product-moment table, it shows that the correlation is "enough" because 0,401 placed between 0,400 $-0,599$. In addition, the null hypothesis was rejected because $r$ table is lower than $r$ observation whether at $5 \%(0,279)$ or at $1 \%(0,361)$ level of significance, meaning that there was a significant correlation between students' activities in STAD model and their interest in learning English. So, it can be concluded that activities in STAD model can influence students' interest because, in STAD model, students can learn the English learning material better.
\end{abstract}

Keywords: Students' activities, STAD model, interest, learning English.

\section{INTRODUCTION}

Regarding build an interesting learning environment, learning should be conducive, so students can be more innovative and involved [1]. During classroom practices, conducive learning should be accomplished to obtain optimum learning results within three cognitive, affective, and psychomotor domains. [2]. Students are a group of people that will be taught, guided, and nurtured towards the achievement of specified learning objectives, students also have a role in teaching and learning and in the implementation process of learning the interaction between teachers and students, and between students with one other student. The interaction between students-students and students-teacher improved the students' learning [3]. During the learning process, 
students use all the basic skills that have it as a base to carry out various activities to obtain the optimal achievement.

However, to get optimal achievement students are influenced by many factors. Hadiwijaya \& Hutasoit (2017) stated that the factors learning achievement is supported by the level of intelligence, talents, interests, attitudes, skills and motivation of a person. Therefore, from all the factors above, interest is one of the important aspects, because interest can influence someone do or not to do something. Sharma \& Pooja (2016) says that interest is a best teacher. It is permanent tendency to notice and remember some of the activities. It means that interest is a persistent tendency in the subject concerned, it is interested in a particular field or something and feel good about working in that field.

Interest is a taste and flavor preferred interest in a thing or activity, without being told. Interest can provide impetus to conduct activities in the learning process. For example, on the issue of global warming (global warming), this issue became the most recent issue being discussed today and threaten the survival of all creatures. Therefore, students are expected to care with this issue and actively they can have the attention with this problem. Slameto (2003) states that the greatness of interest seen from how much revenue would a relationship between yourself with something outside of us, the stronger and closer relationship, the greater of interest owned.

Based on the explanations above, learners must have the big interest to make a learning activity is meaningful.

Besides interest, a learning model plays an important role in achieving student's achievement. Student Teams Achievement Division (STAD) is a type of a learning model developed by Slavin and his colleagues. STAD is one of the most significant CL models, which has been influential in bringing about positive effects in multiple grades and subjects (Slavin, 1995). Student Teams Achievement Divisions (STAD) offered opportunities for students to work together as a form of learning involving community members. (Taniredja, Faridli, \& Harmianto, 2011).

Type STAD cooperative learning is a model that was developed to engage students in reviewing the material covered in the lesson. Team members use work sheets or other study devices to help them master the academic material and they help one another learn the materials through tutoring, quizzing, or carrying on team discussions. STAD is not completely static and improves versatility. (Johnson, Johnson, \& Stanne, 2000) and it could be used in any subjects (Tran, 2013; Vaughan, 2002; Wyk, 2011)

Futhermore, Mohamad in Efi (2007) says that STAD designed to motivate students to be re-energized. In this model, students are grouped in teams with members of 4 students on each team. The team formed by heterogeneous performance level, gender, and ethnicity.

In cooperative learning STAD model, the students learn and form their knowledge based on their experience and their ability in work together with their friend 
in the groups to finish the task that is given to them. The teacher is as a facilitator that help the students to manage and control the learning process.

MAN 039 Tembilahan is one of the schools that teach English language to the students. The students are given many materials and methods of learning in order that they can have big interest for this subject, not only in the classroom, but also outside of classroom English language is taught. Some of the students who learn English feel that they do not get the benefit from learning of English language, even they have learned English from the junior high school, but they still do not have big interest for this subject.

From on the fact the researcher found that there were some phenomena happened to students' interest that have impact for the activities in learning English. The phenomena were some students did not give attention for their teacher, some students were not joining in learning process, such as they are lazy to take notes, make summarize, and read the material, some students were still outside of class when the English lesson would be begun, some students made noise during the English lesson.

Based on the phenomena above, determining the value of an interest in English lesson to encourage the desired activity, is necessary to be used as a benchmark to determine the next steps to improve learning. It is necessary for research entitled, "A Correlational Study Investigating Students' Activities in STAD Model and Their Interest in Learning English at First Year of MAN 039 Tembilahan"

\section{METHODS}

The study was a correlational study that designed to determine whether and how a set of variables are related or to these hypotheses regarding expected relationships. There are two variables in this research, independent and dependent variables. The students' activities are as independent, and dependent is the students' interest. These variables can be seen as follows :

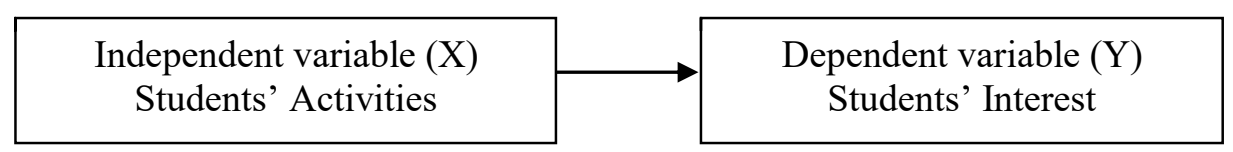

This research was done in MAN 039 Tembilahan. MAN 039 Tembilahan was an Islamic school that has adressed at Jln. Pelajar. This school has been built for 35 years. The participants are 50 students in first year that use STAD model in learning process involved : X8, X9, X10. The instruments used in this study were observation sheet and questionnaire. Students' observation sheet was used by researchers to perceive student activity. Perception by using observation sheet in each activity perceived to be assigned value from 1 to 4 and the researchers gave the questionnaire for the students to know how big the student's interest. Type of questionnaire used was closed questionnaire. To analyse the data, the researhers used SPSS window program. 


\section{RESULT AND DISCUSSION}

This research consists of two variables. They are independent variable symbolized by $\mathrm{X}$ and dependent variable symbolized by $\mathrm{Y}$. The independent variable is students' activities in STAD model, while the dependent variable is a variable which is affected by the independent variable namely students' interest in learning English.

\section{a. The correlation between students' activities in STAD model and their interest}

In order to obtain the data in this research, the researcher use observation sheet and questionnaire. Observation sheet is used to find out the category of students' activities in STAD model and give questionnaire consisting of seven items to the students. It is used to find out the students' interest in learning English. In answering each item of questionnaire, the students have to choose the following option. Namely, strongly agree (SA), Agree (A), Undecided (U), Disagree (D), strongly disagree (SD). This research presented the scores of students' activities in STAD model (variable X) and their interest in learning English (variable Y).

\section{Table 1}

The Frequency Table of Students' Activities in STAD model

\begin{tabular}{|rc|c|c|c|c|}
\hline & Frequency & Percent & Valid Percent & $\begin{array}{c}\text { Cumulative } \\
\text { Percent }\end{array}$ \\
\hline Valid 21.00 & 3 & 6.0 & 6.0 & 6.0 \\
22.00 & 5 & 10.0 & 10.0 & 16.0 \\
23.00 & 7 & 14.0 & 14.0 & 30.0 \\
24.00 & 7 & 14.0 & 14.0 & 44.0 \\
25.00 & 13 & 26.0 & 26.0 & 70.0 \\
26.00 & 10 & 20.0 & 20.0 & 90.0 \\
27.00 & 4 & 8.0 & 8.0 & 98.0 \\
28.00 & 1 & 2.0 & 2.0 & 100.0 \\
Total & 50 & 100.0 & 100.0 & \\
\hline
\end{tabular}

Valid with the highest score is 28.00 in frequency of 1 and the lowest is With the score 21.00 in frequency of 3 . 


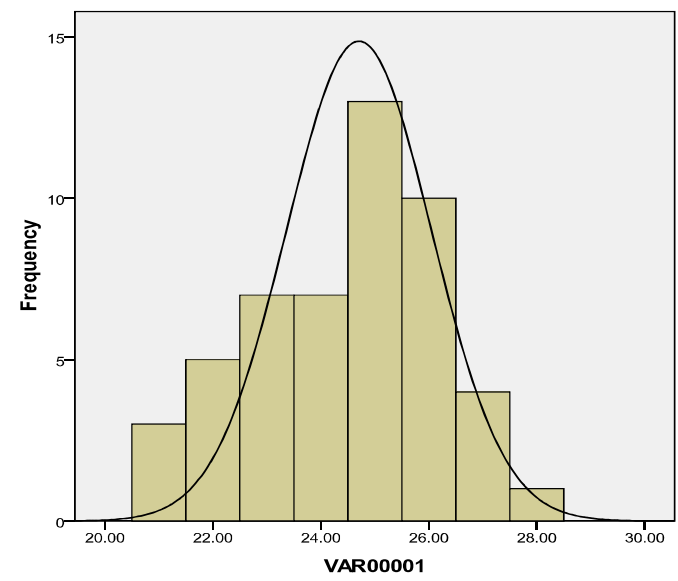

Mean $=24.46$
Std. Devis. $=1.74$
$N=50$

Fig. 1. Students' Activities in STAD model

Table 2

The Frequency of Students' Interest in Learning English

\begin{tabular}{|c|c|c|c|c|c|}
\hline & & Frequency & Percent & Valid Percent & $\begin{array}{c}\text { Cumulative } \\
\text { Percent }\end{array}$ \\
\hline \multirow[t]{16}{*}{ Valid } & 10.00 & 1 & 2.0 & 2.0 & 2.0 \\
\hline & 12.00 & 5 & 10.0 & 10.0 & 12.0 \\
\hline & 13.00 & 2 & 4.0 & 4.0 & 16.0 \\
\hline & 15.00 & 5 & 10.0 & 10.0 & 26.0 \\
\hline & 16.00 & 5 & 10.0 & 10.0 & 36.0 \\
\hline & 17.00 & 2 & 4.0 & 4.0 & 40.0 \\
\hline & 18.00 & 2 & 4.0 & 4.0 & 44.0 \\
\hline & 19.00 & 2 & 4.0 & 4.0 & 48.0 \\
\hline & 20.00 & 8 & 16.0 & 16.0 & 64.0 \\
\hline & 21.00 & 4 & 8.0 & 8.0 & 72.0 \\
\hline & 22.00 & 7 & 14.0 & 14.0 & 86.0 \\
\hline & 23.00 & 3 & 6.0 & 6.0 & 92.0 \\
\hline & 24.00 & 1 & 2.0 & 2.0 & 94.0 \\
\hline & 25.00 & 1 & 2.0 & 2.0 & 96.0 \\
\hline & 26.00 & 1 & 2.0 & 2.0 & 98.0 \\
\hline & 28.00 & 1 & 2.0 & 2.0 & 100.0 \\
\hline
\end{tabular}




\begin{tabular}{|c|c|c|c|c|c|}
\hline & & Frequency & Percent & Valid Percent & $\begin{array}{c}\text { Cumulative } \\
\text { Percent }\end{array}$ \\
\hline \multirow[t]{17}{*}{ Valid } & 10.00 & 1 & 2.0 & 2.0 & 2.0 \\
\hline & 12.00 & 5 & 10.0 & 10.0 & 12.0 \\
\hline & 13.00 & 2 & 4.0 & 4.0 & 16.0 \\
\hline & 15.00 & 5 & 10.0 & 10.0 & 26.0 \\
\hline & 16.00 & 5 & 10.0 & 10.0 & 36.0 \\
\hline & 17.00 & 2 & 4.0 & 4.0 & 40.0 \\
\hline & 18.00 & 2 & 4.0 & 4.0 & 44.0 \\
\hline & 19.00 & 2 & 4.0 & 4.0 & 48.0 \\
\hline & 20.00 & 8 & 16.0 & 16.0 & 64.0 \\
\hline & 21.00 & 4 & 8.0 & 8.0 & 72.0 \\
\hline & 22.00 & 7 & 14.0 & 14.0 & 86.0 \\
\hline & 23.00 & 3 & 6.0 & 6.0 & 92.0 \\
\hline & 24.00 & 1 & 2.0 & 2.0 & 94.0 \\
\hline & 25.00 & 1 & 2.0 & 2.0 & 96.0 \\
\hline & 26.00 & 1 & 2.0 & 2.0 & 98.0 \\
\hline & 28.00 & 1 & 2.0 & 2.0 & 100.0 \\
\hline & Total & 50 & 100.0 & 100.0 & \\
\hline
\end{tabular}

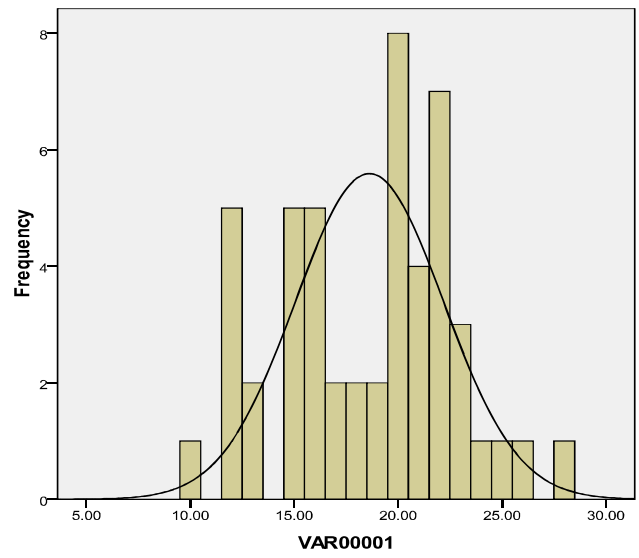

Fig. 2. Students' Interest in Learning English 
Table 3

The Correlation between Student's Activities and Interest

\begin{tabular}{|cc|c|c|}
\hline & $\begin{array}{c}\text { Students' } \\
\text { Activities in } \\
\text { STAD } \\
\text { model }\end{array}$ & $\begin{array}{c}\text { Students' } \\
\text { Interest in } \\
\text { learning } \\
\text { English }\end{array}$ \\
\hline $\begin{array}{c}\text { Students' } \\
\text { Activities in } \\
\text { STAD } \\
\text { model }\end{array}$ & Pearson Correlation & 1 & $.410^{* *}$ \\
\hline $\begin{array}{c}\text { Students' (2-tailed) } \\
\text { Interest in } \\
\text { learning } \\
\text { English }\end{array}$ & Pearson Correlation & $.410^{* *}$ & 1 \\
.003 & 50 \\
\hline
\end{tabular}

**. Correlation is significant at the 0.01 level (2-tailed).

\section{b. The factors influencing students' interest in learning English}

The questionnaire refers to the factors that can influence the students' interest in learning English. There were ten statements in this item that can represent the major factors. All of the statements are going to be presented and calculated in percentage that can be seen on the tables below:

Table 4

I Have a Passion and a Strong Incentive to Learn English.

\begin{tabular}{|l|c|c|}
\hline \multicolumn{1}{|c|}{ Option } & Frequency & Percentage \\
\hline Strongly agree & 10 & 20 \\
Agree & 8 & 16 \\
Undecided & 23 & 46 \\
Disagree & 8 & 16 \\
Strongly disagree & 1 & 2 \\
& & $100 \%$ \\
\hline \multicolumn{1}{|c|}{ Amount } & 50 & \\
\hline
\end{tabular}

The table above shows that there were 10 respondents $(20 \%)$ who answered strongly agree, 8 respondents $(16 \%)$ who answered agree, 23 respondent $(46 \%)$ who answered undecided, 8 respondents $(16 \%)$ who answered disagree, 1 respondent $(2 \%)$ who 
answered strongly disagree. So, the highest is "undecided", it means that the students do not have less a passion and a strong incentive to learn English.

Table 5

The Direct Surroundings is Very Supportive Classroom Atmosphere of the Learning Process.

\begin{tabular}{|l|c|c|}
\hline \multicolumn{1}{|c|}{ Option } & Frequency & Percentage \\
\hline Strongly agree & 13 & 26 \\
Agree & 12 & 24 \\
Undecided & 20 & 40 \\
Disagree & 4 & 8 \\
Strongly disagree & 0 & 0 \\
\hline \multicolumn{1}{|c|}{ Amount } & 50 & $100 \%$ \\
\hline
\end{tabular}

The table above shows that there were 13 respondents (26\%) who answered strongly agree, 12 respondents (24\%) who answered agree, 20 respondents (40\%) who answered undecided, 4 respondent $(8 \%)$ who answered disagree and no respondent to strongly disagree. So, the highest is "undecided", it means that most of the students choose the direct surroundings is not supportive learning process

Table 6

Ways of Teacher in Delivering Learning is Very Interesting.

\begin{tabular}{|l|c|c|}
\hline \multicolumn{1}{|c|}{ Option } & Frequency & Percentage \\
\hline Strongly agree & 22 & 44 \\
Agree & 12 & 24 \\
Undecided & 4 & 8 \\
Disagree & 5 & 10 \\
Strongly disagree & 9 & 18 \\
& & $100 \%$ \\
\hline \multicolumn{1}{|c|}{ Amount } & 50 & \\
\hline
\end{tabular}

The table above shows that there were 22 respondents (44\%) who answered strongly agree, 12 respondents $(24 \%)$ who answered agree, 4 respondents $(8 \%)$ who answered undecided, 5 respondents $(10 \%)$ who answered disagree, 9 respondents (18\%) who answered strongly disagree. So, the highest is "strong agree", it means that most of students like the ways of teacher teaches them. 
Table 7

Facilities and Infrastructure are Very Adequate Learning in The Classroom.

\begin{tabular}{|l|c|c|}
\hline \multicolumn{1}{|c|}{ Option } & Frequency & Percentage \\
\hline Strongly agree & 19 & 38 \\
Agree & 18 & 36 \\
Undecided & 3 & 6 \\
Disagree & 4 & 8 \\
Strongly disagree & 6 & 12 \\
\hline \multicolumn{1}{|c|}{ Amount } & 50 & $100 \%$ \\
\hline
\end{tabular}

The table above shows that there were 19 respondents (38\%) who answered strongly agree, 18 respondents (36\%) who answered agree, 3 respondents $(6 \%)$ who answered undecided, 4 respondents $(8 \%)$ who answered disagree, 6 respondent ( $12 \%)$ who answered strongly disagree. So, the highest is " strongly agree", it means that facilities and infrastructure are very adequate learning in the classroom.

Table 8

Teacher Used Varieties of Media

\begin{tabular}{|l|c|c|}
\hline \multicolumn{1}{|c|}{ Option } & Frequency & Percentage \\
\hline Strongly agree & 8 & 16 \\
Agree & 10 & 20 \\
Undecided & 15 & 30 \\
Disagree & 17 & 34 \\
Strongly disagree & 0 & 0 \\
& & $100 \%$ \\
\hline \multicolumn{1}{|c|}{ Amount } & 50 & \\
\hline
\end{tabular}

The table above shows that there were 8 respondents (16\%) who answered strongly agree, 10 respondents $(20 \%)$ who answered agree, 15 respondent $(30 \%)$ who answered undecided, 17 respondents $(34 \%)$ who answered disagree, no respondent ( $0 \%)$ who answered strongly disagree. So, the highest was "Disagreed", it means that media used by teacher when teaching is not diverse.

Table 9. Learning Atmosphere in the Classroom is Quiet and Conducive

\begin{tabular}{|l|c|c|}
\hline \multicolumn{1}{|c|}{ Option } & Frequency & Percentage \\
\hline Strongly agree & 3 & 6 \\
Agree & 12 & 24 \\
Undecided & 7 & 14 \\
Disagree & 18 & 36 \\
Strongly disagree & 10 & 20 \\
& & $100 \%$ \\
\hline \multicolumn{1}{|c|}{ Amount } & 50 & \\
\hline
\end{tabular}


The table above shows that there were 3 respondents $(6 \%)$ who answered strongly agree, 12 respondents $(24 \%)$ who answered agree, 7 respondents $(14 \%)$ who answered undecided, 18 respondents (36\%) who answered disagree, 10 respondents (20\%) who answered strongly disagree. so, the highest is "disagreed", it means that some of students do not like learning atmosphere in the classroom is quiet and conducive.

Table 11. My Family Always Give Me Support to Learn English

\begin{tabular}{|l|c|c|}
\hline \multicolumn{1}{|c|}{ Option } & Frequency & Percentage \\
\hline Strongly agree & 6 & 12 \\
Agree & 10 & 20 \\
Undecided & 23 & 46 \\
Disagree & 9 & 18 \\
Strong disagree & 2 & 4 \\
& & $100 \%$ \\
\hline \multicolumn{1}{|c|}{ Amount } & 50 & \\
\hline
\end{tabular}

The table above shows that there were 6 respondents $(12 \%)$ who answered strongly agree, 10 respondents $(20 \%)$ who answered agree, 23 respondent (46\%) who answered undecided, 9 respondents (18\%) who answered disagree, 2 respondents ( 4\%) who answered strongly disagree. So, the highest is "undecided", it means that most of students get less support to learn English.

Table 10. I Have many of English Resources in My House

\begin{tabular}{|l|c|c|}
\hline \multicolumn{1}{|c|}{ Option } & Frequency & Percentage \\
\hline Strongly agree & 6 & 12 \\
Agree & 9 & 18 \\
Undecided & 20 & 40 \\
Disagree & 15 & 30 \\
Strongly disagree & 0 & 0 \\
& & \\
\hline \multicolumn{1}{|c|}{ Amount } & 50 & $100 \%$ \\
\hline
\end{tabular}

The table above shows that there were 6 respondents $(12 \%)$ who answered strongly agree, 9 respondents (18\%) who answered agree, 20 respondents (40\%) who answered undecided, 15 respondents $(30 \%)$ who answered disagree, no respondent ( $0 \%$ ) who answered strongly disagree. So, the highest is "undecided". It means that most of students have less resources of English. 
Table 12. Teacher is Fair in Learning Process

\begin{tabular}{|l|c|c|}
\hline \multicolumn{1}{|c|}{ Option } & Frequency & Percentage \\
\hline Strongly agree & 35 & 70 \\
Agree & 7 & 14 \\
Undecided & 8 & 16 \\
Disagree & 0 & 0 \\
Strongly disagree & 0 & 0 \\
\hline \multicolumn{1}{|c|}{ Amount } & 50 & $100 \%$ \\
\hline
\end{tabular}

The table above shows that there were 35 respondents (70\%) who answered strongly agree, 7 respondents (14\%) who answered agree, 8 respondents (16\%) who answered undecided, no respondents who answered disagree and strongly disagree. so, the highest is "strong agree", it means that most of the students agree that teacher is fair in learning process.

Table 13. I Have many Friends that can Share the Information about English

\begin{tabular}{|l|c|c|}
\hline \multicolumn{1}{|c|}{ Option } & Frequency & Percentage \\
\hline Strongly agree & 7 & 14 \\
Agree & 23 & 46 \\
Undecided & 8 & 16 \\
Disagree & 12 & 24 \\
Strong disagree & 0 & 0 \\
& & $100 \%$ \\
\hline \multicolumn{1}{|c|}{ Amount } & 50 & \\
\hline
\end{tabular}

The table above shows that there were 7 respondents (14\%) who answered strongly agree, 23 respondents (46\%) who answered agree, 8 respondents $(16 \%)$ who answered undecided, 12 respondents $(24 \%)$ who answered disagree, no respondent $(0 \%)$ who answered strongly disagree. So, the highest is "Agreed". It means that the students have many friends to share the information about English.

\section{CONCLUSION}

Based on the score of product moment by using SPSS, $\mathrm{R}_{\mathrm{xy}}$ is $(0,410)$ : it showed there was significant correlation between students' activities in STAD model and their interest in learning English. Referring to product moment table, it shows that the correlation is "enough", because 0,401 placed between 0,400-0,599.

On the other hand, the null hypothesis was rejected because $r$ table is lower than $\mathrm{r}$ observation whether at $5 \%(0,279)$ or at $1 \%(0,361)$ level of significant, meaning that there was a significant correlation between students' activities in STAD model and their interest in learning English at the first year of MAN 039 Tembilahan. 
In addition, it means that activities in STAD model can influence students' interest, because in STAD model, students can learn the learning material better, although, it is just in the level enough.

\section{ACKNOWLEDGEMENTS}

We warmly thank the Madrasah Aliyah Negeri 039 Tembilahan for allowing us in conducting the project about the correlation between students' Activities in STAD Model and their interest in learning English and our research partners for their commitment and contribution: Melda Yeni, Rahmatunnisah and Dedi Saputra.

\section{REFERENCES}

[1] Efi. 2007. Perbedaan hasil belajar biologi antara siswa yang diajar melalui pendekatan cooperative learning tipe jigsaw dengan tipe STAD. Skripsi. UIN Syarif Hidayatullah. Jakarta.

[2] Hadiwijaya, H., \& Hutasoit, G. (2017). Effect of Emotional Intelligence on Student Learning Achievement. GUIDENA: Jurnal Ilmu Pendidikan, Psikologi, Bimbingan dan Konseling. 7 (1).

[3] Hurst, B., Wallace, R., \& Nixon, S. B. (2013). The Impact of Social Interaction on Student Learning. Reading Horizons: A Journal of Literacy and Language Arts, 52 (4). Retrieved from https://scholarworks.wmich.edu/reading_horizons/vol52/iss $4 / 5$

[4] Johnson, D. W., Johnson, R. T., \& Stanne, M. B. (2000). Cooperative learning methods: A meta-analysis

[5] Sharma, H., L \& Pooja. (2017). Enhancing students' interest in English language via multimedia presentation. International Journal of Applied Research. 2 (1). 275-281

[6] Slameto. 2003. Belajar dan Faktor-Faktor yang Mempengaruhi. Rineka Cipta. Jakarta

[7] Slavin, R. E.1995. Cooperative learning: Theory, research, and practice. Englewood Cliffs, NJ: Prentice-Hall.

[8] Suyono, S., \& Hariyanto, H. (2011). Belajar dan Pembelajaran Teori dan Konsep Dasar. Bandung: PT Remaja Rosda.

[9] Taniredja, T., Faridli, E. M., \& Harmianto, S. (2011). Model-model pembelajaran inovatif. Alfabeta.

[10] Tran, V. D. (2013). Effects of Student Teams Achievement Division ( STAD ) on Academic Achievement, and Attitudes of Grade 9th Secondary School Students towards Mathematics. International Journal of Science, 2, 1-15.

[11] Vaughan, W. (2002). Effects of cooperative learning on achievement and attitude among students of color. Journal of Educational Research, 95(6), 359-364. https://doi.org/10.1080/00220670209596610

[12] Wardani, N. S., Winanto, A., \& others. (2012). Asesmen Pembelajaran SD: Bahan Belajar Mandiri. Widya Sari.

[13] Wyk, M. M. van. (2011). The Effects of Teams-Games-Tournaments on Achievement, Retention, and Attitudes of Economics Education Students. Journal of Social Sciences, 26(3), 183-193. https://doi.org/10.1080/09718923.2011.11892895 